\title{
PENEGAKAN HUKUM PENATAAN RUANG DALAM RANGKA MEWUJUDKAN PEMBANGUNAN BERKELANJUTAN
}

\author{
(Spatial Plan Law Enforcement to Achieve Sustainable Development)
}

\author{
Ahmad Jazuli \\ Badan Penelitian dan Pengembangan Kebijakan \\ Kementerian Hukum dan HAM RI \\ Jalan Raya H.R. Rasuna Said Kav.4-5 Kuningan Jakarta Selatan \\ Email: joevikage_75@yahoo.co.id
}

Naskah diterima: 4 April 2017; revisi: 9 Agustus 2017; disetujui: 21 Agustus 2017

\begin{abstract}
Abstrak
Sinergitas antara komponen lingkungan hidup; masyarakat; dan pengelola lingkungan dalam penataan ruang diharapkan dapat mewujudkan tujuan pembangunan Indonesia dalam meningkatkan kesejahteraan masyarakat. Namun yang terjadi masih menunjukan rendahnya pemahaman pentingnya pengelolaan sumber daya alam dan lingkungan hidup secara berkesinambungan, terjadinya peningkatan pelanggaran penataan ruang, dan lemahnya penegakan hukum terhadap pelanggaran penataan ruang. Penelitian ini mencoba menjawab permasalahan: bagaimana pelaksanaan penegakan hukum penataan ruang dan bagaimana solusinya dalam upaya mewujudkan pembangunan berkelanjutan. Melalui metode yuridis normatif yang bersifat deskriptif analisis, disimpulkan bahwa implementasi penegakan hukum terhadap penyimpangan penataan ruang masih belum konsisten karena masih terjadinya pelanggaran penataan ruang serta ringannya sanksi yang diberikan. Oleh karena itu harus ada komitmen dan political will yang kuat pemerintah dalam penegakan hukumnya yang dilakukan secara cermat, proporsional, dan komprehensif demi perbaikan kondisi lingkungan hidup yang lebih baik serta memperkuat partisipasi masyarakat dalam penyusunan rencana, pemanfaatan, dan pengendaliannya, sehingga kebijakan penataan ruang berdampak positif bagi pemerintah, korporasi, dan masyarakat.
\end{abstract}

Kata Kunci: penegakan hukum, penataan ruang, pembangunan berkelanjutan

\begin{abstract}
Synergy between environment; society; and environment management in spatial planning is important tto achieve Indonesia development objective which is to increase social welfare. However, there's still low understanding on the importance of sustainable natural resource management, increasing number of spatial plan violation, and weak law enforcement toward spatial plan violation. This research tries to answer the problem about how law enforcement toward spatial plan violation can support sustainable development effort. Through juridical normative method with descriptive analytic research characteristic, this research conclude that law enforcement toward spatial plan violation is still not consistent. Spatial plan violation still happens and the sanctions imposed are weak. Government needs to show strong commitment and political will where law enforcement is carried in a detailed, proportional, and comprehensive way to make better environment. Public participation in planning, using and controlling the spatial plan is also needed to be strengthened so that it may give positive impact to government, corporate, and society.
\end{abstract}

Keywords: law enforcement, spatial planning, sustainable development 


\section{A. Pendahuluan}

Salah satu cara suatu negara untuk dikenal dunia internasional, yakni melalui peningkatan kualitas hidup. Hal ini juga sesuai dengan butir Nawacita yang mengatakan bahwa salah satu tujuan pembangunan di Indonesia adalah untuk meningkatkan kualitas hidup manusia.

Ruang wilayah Negara Kesatuan Republik Indonesia, baik sebagai kesatuan wadah yang meliputiruang darat, ruang laut, dan ruangudara, termasuk ruang di dalam bumi maupun sebagai sumber daya, merupakan karunia Tuhan Yang Maha Esa kepada bangsa Indonesia yang perlu disyukuri, dilindungi dan dikelola secara berkelanjutan untuk sebesar-besarnya kemakmuran rakyat sebagaimana diamanatkan dalam Pasal 33 Ayat (3) Undang-Undang Dasar Negara Republik Indonesia Tahun 1945 (UUD NRI 1945) yang menegaskan bahwa "Bumi dan air dan kekayaan alam yang terkandung didalamnya dikuasai oleh negara dan dipergunakan untuk sebesar-besarnya kemakmuran rakyat".

Untuk mewujudkan amanat tersebut maka dibentuklah Undang-Undang Nomor 26 tahun 2007 tentang Penataan Ruang (UU
Penataan Ruang), yang menyatakan bahwa negara menyelenggarakan penataan ruang yang pelaksanaan wewenangnya dilakukan oleh Pemerintah pusat dan daerah (Pasal 7 ayat (2) dengan tetap menghormati hak yang dimiliki oleh setiap orang sesuai dengan ketentuan peraturan perundang-undangan (Pasal ayat (3), Tambahan Lembaran Negara Nomor 4725). Dalam hal penyelenggaraan penataan ruang, tugas negara meliputi dua hal, yaitu; (a) policymaking, ialah penentuan haluan negara; (b) task executing, yaitu pelaksanaan tugas menurut haluan yang telah ditetapkan oleh negara.

Kegiatan penataan ruang terdiri dari 3 (tiga) kegiatan yang saling terkait, yaitu: perencanaan tata ruang, pemanfaatan ruang, dan pengendalian pemanfaatan ruang (gambar 1), dengan produk rencana tata ruang berupa Rencana Tata Ruang Wilayah (RTRW) yang secara hierarki terdiri dari Rencana Tata Ruang Wilayah Nasional (RTRWN), Rencana Tata Ruang Wilayah Provinsi (RTRWP), dan Rencana Tata Ruang Wilayah Kabupaten/Kota (RTRW Kab/kota). Penataan ruang dapat digambarkan seperti berikut:

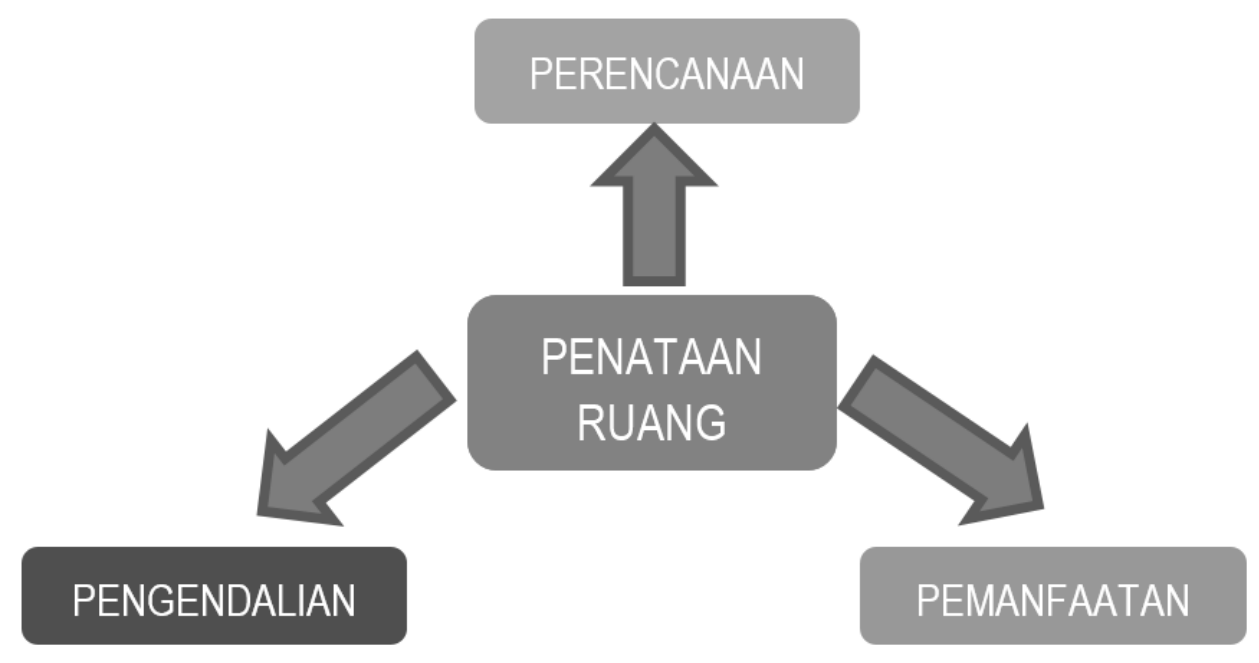

Gambar 1.Penataan Ruang

sumber: diolah dari dalam Pasal 1 Angka 5 UU Tentang Penataan Ruang 
Berdasarkan ketentuan dalam Pasal 1 angka 13 UU Penataan Ruang, bahwa yang dimaksud dengan perencanaan tata ruang adalah suatu proses untuk menentukan struktur ruang dan pola ruang yang meliputi penyusunan dan penetapan rencana tata ruang guna untuk menyerasikan berbagai kegiatan sektor pembangunan, sehingga dalam memanfaatkan lahan dan ruang dapat dilakukan secara optimal, efisien, dan serasi sehingga dihasilkan rencana umum tata ruang dan rencana rinci tata ruang (Pasal 14 UU Penataan Ruang).

Pengertian pemanfaatan ruang dalam ketentuan Pasal 1 angka 14 UU yang sama adalah upaya untuk mewujudkan struktur dan pola ruang sesuai dengan rencana tata ruang melalui penyusunan dan pelaksanaan program serta pembiayaannya. ${ }^{1} \mathrm{Hal}$ ini mengindikasikan bahwa pelaksanaan program pemanfaatan ruang merupakan aktifitas pembangunan, baik yang dilaksanakan oleh pemerintah maupun masyarakat untuk mewujudkan rencana tata ruang yang dilakukan secara bertahap sesuai dengan jangka waktu yang ditetapkan dalam rencana tata ruang.

Sedangkan pengendalian pemanfaatan ruang adalah upaya untuk mewujudkan tertib tata ruang (Pasal 1 angka 15 UU Penataan Ruang) yang dilakukan melalui penetapan zonasi (peraturan zonasi merupakan ketentuan yang mengatur pemanfaatan ruang dan unsurunsur pengendalian yang disusun untuk setiap zona peruntukan sesuai dengan rencana rinci tata ruang), ${ }^{2}$ perizinan, pemberian insentif dan disinsentif,sertapengenaansanksi. Pengendalian pemanfaatan ruang dilakukan sesuai dengan rencana tata ruang untuk meminimalisir adanya ketidaksesuaian pemanfaatan ruang sehingga terjaga kesesuaian pemanfaatan ruang dengan fungsi ruang yang telah ditetapkan rencana tata ruang. $^{3}$

Ketiga rencana tata ruang tersebut harus dapat terangkum di dalam suatu rencana pembangunan sebagai acuan di dalam implementasi perencanaan pembangunan berkelanjutan (sustainable development) di wilayah Indonesia dengan berpedoman pada UU Penataan Ruang sebagaimana dikatakan dalam Pasal 3 bahwa penyelenggaraan penataan ruang bertujuan untuk mewujudkan ruang wilayah nasional yang aman, nyaman, produktif dan berkelanjutan berdasarkan Wawasan Nusantara dan Ketahanan Nasional dengan : a. terwujudnya keharmonisan antara lingkungan alam dan lingkungan buatan; $b$. terwujudnya keterpaduan dalam penggunaan sumber daya alam dan sumber daya buatan dengan memperhatikan sumber daya manusia; dan c. terwujudnya pelindungan fungsi ruang dan pencegahan dampak negatif terhadap lingkungan akibat pemanfaatan ruang. ${ }^{4}$

Pesatnya perkembangan kawasan baik di perkotaan dan pedesaan, selain memberikan dampak positif bagi perkembangan ekonomi, ternyata di sisi lain mengakibatkan timbulnya permasalahan lingkungan, hal ini terlihat dengan semakin kritisnya kondisi lingkungan di Indonesia, yang berdampak pada intensitas bencana alam yang terjadi di berbagai wilayah

http://erepo.unud.ac.id1163230ca82e87cb23dbfe065a21b41e2cdeb5.pdf, (diakses 7 April 2017).

Hasni.Hukum Penataan Ruang dan Penatagunaan Tanah. (Jakarta: PT Raja Grafindo Persada. 2010), hlm. 194.

http://erepo.unud.ac.id1163230ca82e87cb23dbfe065a21b41e2cdeb5.pdf, op. cit.

Laporan Akhir Kajian Hukum Tentang Penegakan Hukum Penataan Ruang dalam Kerangka Otonomi Daerah, (Jakarta: BPHN, 2014) dalam http://www.bphn.go.iddatadocumentslaporan_lengkap.pdf,(diakses 7 April 2017). 
di Indonesia yang salah satu penyebabnya adalah karena pelanggaran tata ruang.

Kementerian Pekerjaan Umum menemukan indikasi pelanggaran tata ruang di 788 lebih di wilayah Jabotabek dan kawasan Puncak serta Cianjur. Pelanggaran tata ruang juga terindikasi terjadi di banyak daerah antara lain di Makasar, dan kawasan situs Trowulan di Jawa Timur. ${ }^{5}$ Bahkan pada tahun 2015, terdapat 105 perusahaan (Kalimantan Tengah) dan 89 perusahaan (Kalimantan Barat) yang diduga melanggar Rencana Tata Ruang Wilayah yang berpotensi kerugian negara sebesar Rp. 21,59 triliun dan sedang dalam penanganan Komisi Pemberantasan Korupsi. ${ }^{6}$ Terkait Kebakaran hutan dan lahan yang terjadi di sejumlah provinsi di Indonesia, berdasarkan data Kementerian Lingkungan Hidup dan Kehutanan (Kementerian LHK) tahun 2015 ada 413 perusahaan yang sedang diselidiki, dan hasilnya 14 perusahaan telah dikenakan sanksi oleh Kementerian Lingkungan Hidup dan Kehutanan dengan rincian 3 perusahaan dicabut izinnya, 7 perusahaan dibekukan izinnya, dan 4 perusahaan menjalani sanksi paksaan pemerintah. ${ }^{7}$

Terjadinya berbagai permasalahan dalam penyelenggaraan penataan ruang di Indonesia karena berbagai hal, antara lain: dominasi kebijakan sektoral yang didasari oleh kepentingan tertentu di tiap sektoral, perencanan tata ruang tanpa Kajian Lingkungan Hidup Strategis (KLHS), ketidaksesuaian antara rencana tata ruang kota/kab, propinsi, dan nasional, rendahnya partisipasi masyarakat dalam penataan ruang, hingga perencanaan pembangunan yang tidak sesuai dengan penataan ruang atau bahkan tanpa disertai rencana tata ruang yang komprehensif. Disisi lain, lemahnya aspek penegakan hukum menjadi salah satu penyebab terjadinya pelanggaran penataan ruang. Kenyataan ini menggambarkan keberadaan UU Penataan Ruang belum mampu dijadikan ruh perbaikan penataan ruang di Indonesia.

Berdasarkan latar belakang tersebut di atas maka ada beberapa permasalahan pokok seperti masih rendahnya pemahaman akan pentingnya pengelolaan SDA dan lingkungan hidup secara berkesinambungan, lemahnya penegakan hukum terkait pelanggaran penataan ruang yang berakibat pada masih terjadinya pelanggaran penataan ruang (pusat dan daerah), masih tingginya tingkat pencemaran lingkungan hidup akibat belum dipatuhinya peraturan di bidang sumber daya alam dan lingkungan hidup, ${ }^{8}$ Serta kurang adanya keselarasan pengaturan antara pemerintah pusat dan daerah. Ketidakselarasan ini menghambat pelaksanaan koordinasi dan melemahkan penegakan hukum. Dan kalau disimpulkan secara garis besar maka akan mengerucut pada Bagaimanakah Implementasi penegakan hukum dalam penataan ruang berdasarkan Undang-Undang Nomor 26 Tahun 2007 tentang Penataan Ruang?, Bagaimanakah solusi yang dilakukan dalam rangka penegakan

ibid.

6 http://kabar24.bisnis.com/read/20151105/16/489087/pelanggaran-tata-ruang-data-194-perusahaan-dikalteng-dan-kalbar-diserahkan-ke-kpk\#\&gid=1\&pid=1, (diakses 8 Agustus 2017, pukul 13.27 WIB).

7 http://pktl.menlhk.go.id/index.php?pg=w2530y2545c2610c2565v2620z2525\&id=k2460, (diakses 8 Agustus 2017, pukul 13.52 WIB).

8 http://www.bappenas.go.id/index.php/download_file/view/9567/1781/. (diakses 26 Februari 2015. pukul 08.37 WIB). 
hukum penataan ruang dalam kerangka mewujudkan pembangunan berkelanjutan?

\section{B. Metode Penelitian}

Tipologi penelitian ini bersifat deskriptif analisis yang bertujuan untuk menggambarkan, menginventarisir, dan menganalisis kondisi yang sebenarnya tentang penegakan hukum terkait penataan ruang guna mewujudkan pembangunan yang berkelanjutan melalui penelitian kepustakaan (library reseach) dengan menekankan pada sumber data sekunder. ${ }^{9}$ Data sekunder yang digunakan dalam penelitian ini dikumpulkan dari sumber primer berupa perundang-undangan. ${ }^{10}$ Data yang sudah terkumpul akan dianalisis dengan penelaahan terhadap peraturan perundang-undangan yang mengatur tentang penataan ruang di Indonesia.

\section{Pembahasan}

Pertumbuhan penduduk yang sangat cepat di Indonesia, diikuti pesatnya pertumbuhan ekonomi dan dinamika sosial kehidupan, menyebabkan meningkatnya kebutuhan akan sarana dan prasarana. Mengantisipasi hal tersebut dan sebagai perwujudan akan pengamalan negara kesejahteraan (Welfare State) yang sesuai dengan Pancasila dan UndangUndang Dasar Negara Republik Indonesia Tahun 1945, maka pemerintah berkewajiban untuk mengatur, menata dan menyelenggarakan pemenuhan kehidupan masyarakat sesuai batas kemampuannya, mengingat wilayah Indonesia yang terdiri lebih dari 17.000 pulau besar dan kecil, baik yang berpenghuni maupun yang tidak berpenghuni, sumber daya alam yang melimpah, hutan, gunung, sungai besar dan kecil, sumber daya hayati, baik di darat, laut maupun udara diatasnya, oleh karena itu diperlukan campur tangan pemerintah dalam pengelolaan sumber daya dan yang menyangkut kehidupan orang banyak. $^{11}$

Hukum dalam pembangunan adalah sebagai salah satu sarana yang harus mampu mendorong proses modernisasi, sejalan dengan fungsi tersebut maka pembentuk undang-undang meletakan berbagai landasan yuridis dalam melakukan berbagai kegiatan pembangunan, salah satunya adalah UU Penataan Ruang ini. ${ }^{12}$

Pembangunan secara makro, terutama pembangunan ekonomi masyarakat, mulai dari pembangunan industri, perumahan, transportasi, perdagangan, perkebunan, pertanian, kelautan/maritim dan lain-lain sudah tentu memerlukan lahan yaitu tempat manusia dan makhluk hidup lainnya melakukan kegiatan dan memelihara kelangsungan hidupnya dan tata ruang berupa wujud struktur ruang dan pola ruang (Pasal 1 ayat ( 1 dan ayat (2) UU Penataan Ruang) yang sangat luas, dengan sendirinya pula harus memperhatikan daya dukung lingkungan, serta merubah lingkungan yang lama menjadi lingkungan yang baru dalam segala aspeknya guna mewujudkan masyarakat yang sejahtera. Ini berarti bahwa

Amirudin \& Zainal Asikin, Pengantar Metode Penelitian Hukum, (Jakarta, Radja Grafindo Persada, 2004), hlm. 118.

10 Ronny Haitijo Soemitro, Metodologi Penemuan Hukum, (Jakarta: Ghalian Indonesia, 1982), hlm. 24.

11 Laporan Akhir BPHN, op.cit.,hlm. 15.

12 Mochtar Kusumaatmadja, Konsep-konsep Hukum dalam Pembangunan, (Bandung: Alumni 2002), hlm. 104. dalam http://prepository.unhas.ac.idbitstreamhandle12345678920523BAB\%20II\%20TINJAUAN\%20PUSTAKA\%20 repository\%20unhas.pdfsequence=1, (diakses 07 April 2017, pukul 10.02 WIB). 
pembangunan dilakukan bukan semata untuk mengeksploitasi lingkungan dengan tidak terkendali (sembarangan) dan hanya untuk mengikuti dorongan keinginan segelintir pihak/ korporasi dalam meraih keuntungan tanpa memikirkan dampaknya di kemudian hari.

Oleh karena itu, penyelenggaraan pembangunan wilayah yang berbasis penataan ruang seharusnya dilakukan secara terpadu dengan melibatkan seluruh pelaku pembangunan (stakeholder) di wilayah setempat dalam pola pembangunan yang berkelanjutan (sustainable development) dengan mengembangkan tata ruang yang humanopolis (mengutamakan kepentingan masyarakat dan menciptakan lingkungan yang asri) berdasar wawasan nusantara dan ketahanan nasional. Atas dasar hal tersebut maka prinsip dasar yang harus dipedomani dan diterapkan dalam mendukung kegiatan tersebut antara lain: 1) menempatkan masyarakat sebagai pelaku yang sangat menentukan dalam proses pemanfaatan ruang; 2) memposisikan pemerintah sebagai fasilitator dalam proses pemanfaatan ruang; 3) menghormati hak yang dimiliki masyarakat serta menghargai kearifan lokal dan keberagaman sosial budayanya; 4) menjunjung tinggi keterbukaan dengan semangat tetap menegakkan etika, dan 5) memperhatikan perkembangan teknologi dan bersikap profesional.

Menindaklanjutkan prinsip dasar tersebut di atas, maka penyusunan pedoman partisipasi masyarakat dalam proses pemanfaatan ruang disusun oleh berbagai komponen, baik pemerintah pusat, daerah, swasta, lembaga swadaya masyarakat, forum warga maupun warga masyarakat secara umum. Pedoman ini diharapkan mampu menjadi bagian pendorong dari kelancaran pelaksanaan otonomi daerah, khususnya bagi peningkatan keterlibatan masyarakat dalam pemanfaatan ruang demi terwujudnya 'good governance'.

Hal ini sejalan dengan pemetaan permasalahan yang menjadi perhatian di dalam Rencana Pembangunan Jangka Panjang Nasional (RPJPN 2005-2025), yaitu antara lain: ${ }^{13}$

1. Kondisi krisis penataan ruang di Indonesia. Hal ini disebabkan pembangunan yang dilakukan di suatu wilayah masih sering dilakukan tanpa mengikuti rencana tata ruang, tidak mempertimbangkan keberlanjutan dan daya dukung lingkungan serta tidak memperhatikan kerentanan wilayah terhadap terjadinya bencana alam. Dampak yang terjadi turunnya kualitas dan kuantitas sumber daya alam dan lingkungan hidup, serta memperbesar resiko timbulnya korban akibat bencana alam.

2. Terjadinya konflik pemanfaatan ruang antar sektor, contohnya konflik antara kehutanan dan pertambangan. Beberapa penyebab utamanya terjadinya permasalahan tersebut adalah (a) belum tepatnya kompetensi sumber daya manusia dalam bidang pengelolaan tata ruang, (b) rendahnya kualitas dari rencana tata ruang, (c) belum diacunya perundangan penataan ruang sebagai payung kebijakan pemanfaatan ruang bagi semua sektor; dan (d) lemahnya penerapan hukum berkenaan dengan pemanfaatan ruang.

3. Keterbatasan akses masyarakat di wilayah tertinggal terhadap pelayanan sosial, ekonomi, dan politik serta terisolir dari wilayah sekitarnya. 
4. Ketertinggalan pembangunan wilayah perbatasan, termasuk pulau-pulau kecil terluar yang memiliki potensi SDA yang cukup besar dan sangat strategis bagi pertahanan dan keamanan negara. Walaupun demikian, pembangunan di beberapa wilayah perbatasan masih sangat jauh tertinggal di bandingkan dengan pembangunan di wilayah negara tetangga. Kondisi soal ekonomi masyarakat yang tinggal di daerah tersebut umumnya jauh lebih rendah dibandingkan dengan kondisi sosial ekonomi warga negara tetangga. Permasalahan utama dari ketertinggalan pembangunan di wilayah perbatasan adalah arah kebijakan pembangunan kewilayahan yang selama ini cenderung berorientasi "inward looking" sehingga seolah-olah kawasan perbatasan hanya menjadi halaman belakang dari pembangunan negara. Akibatnya, wilayahwilayah perbatasan dianggap bukan merupakan wilayah prioritas pembangunan oleh pemerintah pusat maupun daerah. Sementara itu, pulau-pulau kecil yang ada di Indonesia sulit berkembang terutama karena lokasinya sangat terisolasi dan sulit dijangkau, diantaranya banyak yang tidak berpenghuni atau sangat sedikit jumlah penduduknya serta belum banyak tersentuh oleh pelayanan dasar dari pemerintah.

5. Dampak negatif yang ditimbulkan dari kota-kota besar dan metropolitan, antara lain, adalah (1) terjadinya eksploitasi yang berlebihan terhadap sumber daya alam di sekitar kota-kota besar dan metropolitan untuk mendukung dan meningkatkan pertumbuhan ekonomi; (2) konversi lahan pertanian produktif menjadi kawasan pemukiman, perdagangan, dan industri secara terus menerus; (3) menurunnya kualitas lingkungan fisik kawasan perkotaan akibat terjadinya perusakan lingkungan dan timbulnya polusi; (4) menurunnya kualitas hidup masyarakat di perkotaan karena permasalahan sosial-ekonomi; serta (5) tidak mandiri dan terarahnya pembangunan kota-kota baru sehingga justru menjadi tambahan beban bagi kota inti.

Memperhatikan permasalahan-permasalahan tersebut di atas yang dapat terjadi baik secara vertikal maupun horizontal, maka di dalam penyelenggaraan penataan ruang harus dilakukan berdasarkan asas-asas yang diatur dalam UU Penataan Ruang, yaitu:

a. Keterpaduan: bahwa penataan ruang diselenggarakan dengan mengintegrasikan berbagai kepentingan yang bersifat lintas sektoral, dan lintas pemangku kepentingan (antara lain pemerintah pusat, pemerintah daerah, dan masyarakat).

b. Keserasian, keselarasan, dan keseimbangan: bahwa penataan ruang diselenggarakan dengan mewujudkan keserasian antara struktur ruang dan pola ruang, keselarasan antara kehidupan manusia dengan lingkungannya, keseimbangan pertumbuhan dan perkembangan antar daerah serta antara kawasan perkotaan dan kawasan perdesaan.

c. Keberlanjutan: bahwa penataan ruang di selenggarakan dengan menjamin kelestarian dan kelangsungan daya dukung dan daya tampung lingkungan dengan memperhatikan kepentingan generasi mendatang.

d. Keberdayagunaan dan keberhasilgunaan: bahwa penataan ruang diselenggarakan dengan mengoptimalkan manfaat ruang dan sumber daya yang terkandung di dalamnya serta menjamin terwujudnya tata ruang yang berkualitas. 
e. Keterbukaan: bahwa penataan ruang diselenggarakan dengan memberikan akses yang seluas-luasnya kepada masyarakat untuk mendapatkan informasi berkaitan dengan penataan ruang.

f. Kebersamaan dan kemitraan: bahwa penataan ruang diselenggarakan dengan mengutamakan kepentingan masyarakat.

g. Kepastian hukum dan keadilan: bahwa penataan ruang diselenggarakan dengan berlandaskan hukum/ketentuan peraturan perundang-undangan dan bahwa penataan ruang dilaksanakan dengan mempertimbangkan rasa keadilan masyarakat serta melindungi hak dan kewajiban semua pihak secara adil dengan jaminan kepastian hukum.

h. Akuntabilitas: bahwa penyelenggaraan penataan ruang dapat di pertanggung jawabkan, baik prosesnya, pembiayaannya, maupun hasilnya. ${ }^{14}$

Berdasarkanasas-asastersebut, UU penataan ruang menegaskan bahwa penyelenggaraan penataan ruang dilakukan oleh pemerintah dengan melibatkan peran masyarakat dalam penyusunan rencana tata ruang, pemanfaatan ruang, dan pengendalian penataan ruang. Namun dalam implementasinya, pelibatan masyarakat dalam penataan ruang menjadi aspek yang sering kali terabaikan. Jikapun terlaksana, pelibatan masyarakat hanya sebatas pemberian informasi dan konsultasi (formalitas), sehingga ketika terjadi permasalahan di kemudian hari, maka masyarakat lah yang akan merasakan akibatnya, padahal tujuan penataan ruang adalah menciptakan hubungan yang serasi dan harmonis antara berbagai kegiatan pada wilayah-wilayah sehingga akan mempercepat proses tercapainya kemakmuran dan terjaminnya kelestarian lingkungan hidup. ${ }^{15}$ Dengan demikian konsep penataan ruang yang berusaha menjamin adanya kelangsungan pembangunan yang berkelanjutan harus menjadi dasar acuan bagi upaya pengelolaan dan pemanfaatan serta pemeliharaan lingkungan hidup. ${ }^{16}$ Oleh karena itu pemerintah harus menggiatkan dan memperkuat partisipasi masyarakat dalam hal menjaga kelestarian alam seperti melakukan program reboisasi, pemberdayaan masyarakat adat dalam menjaga hutan lindung, sosialisasi tentang pentingnya menjaga kelestarian alam dan lingkungannya serta menjadikan masyarakat sebagai pengawas terhadap lingkungan yang menjadi tempat kehidupannya.

\section{Implementasi penegakan hukum dalam penataan ruang berdasarkan Undang-Undang Nomor 26 Tahun 2007}

Penegakan hukum merupakan rangkaian proses untuk menjabarkan nilai, ide, cita yang cukup abstrak yang menjadi tujuan hukum. Nilai-nilai tersebut harus mampu diwujudkan dalam realitas nyata (dapat diimpelementasikan atau tidak). Menurut Soerjono Soekanto, secara konsepsional inti dan arti penegakan hukum terletak pada kegiatan menyerasikan hubungan nilai-nilai yang terjabarkan di dalam kaidahkaidah yang mantap dan mengejawantah sikap dan tindak sebagai rangkaian penjabaran nilai 
tahap akhir, untuk menciptakan, memelihara dan mempertahankan kedamaian pergaulan hidup. ${ }^{17}$ Menurut Satjipto Rahardjo, penegakan hukum pada hakikatnya merupakan penegakan ide-ide atau konsep-konsep yang abstrak tersebut. Penegakan hukum merupakan usaha untuk mewujudkan ide-ide tersebut menjadi kenyataan. ${ }^{18}$

Penegakan hukum sebagai sarana untuk mencapaitujuan hukum, maka sudah semestinya seluruh energi dikerahkan agar hukum mampu bekerja untuk mewujudkan nilai-nilai moral dalam hukum. Kegagalan hukum untuk mewujudkan nilai hukum tersebut merupakan ancaman bahaya akan bangkrutnya hukum yang ada. Hukum yang miskin implementasi terhadap nilai-nilai moral akan berjarak serta terisolasi dari masyarakatnya. Keberhasilan penegakan hukum akan menentukan serta menjadi barometer legitimasi hukum di tengahtengah realitas sosialnya. ${ }^{19}$

Penegakan hukum merupakan suatu bentuk konkrit penerapan hukum dalam masyarakat yang mempengaruhi perasaan hukum, kepuasan hukum dan kebutuhan atau keadilan hukum masyarakat. ${ }^{20}$ Dalam pandangan umum, penegakan hukum identik dengan proses yang terjadi pada lembaga-lembaga penegak hukum seperti Kepolisian, Kejaksaan, Pengadilan, Lembaga Pemasyarakatan dikenal sebagai penegakan hukum pro-justisia yang sebenarnya hanyalah sebagian kecil dari sebuah sistem penegakan hukum, yaitu hukum pidana saja. ${ }^{21}$

Oleh karena itu, berbicara masalah penegakan hukum tidak dapat dilepaskan dari pengertian sistem hukum itu sendiri, dimana didalamnya tercakup tiga komponen yang tidak terpisahkan satu dengan yang lain, yaitu struktur hukum, substansi hukum dan budaya hukum. ${ }^{22}$ Sehingga untuk menegakkan hukum secara optimal wajib memperhatikan ketiga komponen tersebut.

Berkenaan dengan dinamika di tengah masyarakat terkait tata ruang, telaahan kritis terhadap UU Penataan Ruang adalah sebagai berikut: (1) tata ruang merupakan konsep dinamis, oleh karena dipengaruhi oleh kondisi sosial, ekonomi dan budaya serta teknologi, sehingga dalam pelaksanaannya tata ruang hendaknya memperhatikan kondisi-kondisi tersebut; (2) dalam penerapan konsep tata ruang tidak bisa dilakukan secara kaku dan rigit, oleh karena itu secara periodik membutuhkan revisi berdasarkan cakupan tentang alam dan perkembangan teknologi dalam membangun lingkungan buatan; (3) dalam hal visi, pengendalian dengan memperhitungkan daya tampung dan daya dukung lingkungan terhadap berbagai acuan normatif; (4) dalam menentukan ketentuan sanksi, hendaknya memperhatikan ketentuan dari Undang-Undang Penataan Ruang, terkecuali jika suatu tindakan

17 Laporan Akhir BPHN, op. cit.,hlm. 8.

18 Satjipto Rahardjo, Masalah Penegakan Hukum Suatu Tinjauan Sosiologis, (Bandung: Sinar Baru, 2009), hlm. 15.

19 Laporan Akhir BPHN, op. cit., hlm. 8.

20 Bagir Manan, Penegakan Hukum Yang Berkeadilan, dalam Bagir Manan, Menemukan Hukum Suatu Pencarian, (Jakarta: Asosiasi Advokat Indonesia, 2009), hlm. 52.

21 Rahayu Prasetianingsih, Negara Hukum yang Berkeadilan, (Bandung: Pusat Studi Kebijakan Negara, Fakultas Hukum UNPAD, 2011), Cetakan Pertama, hlm. 553.

22 Lawrence M Friedman, 1984, Hukum Amerika, Sebuah Pengantar, Terjemahan Wishnu Basuki, (Jakarta: Tatanusa Indonesia, 2001), hlm. 7. 
yang berkaitan dengan penataan ruang yang mengandung unsur pidana; dan (5) penegakan hukum adalah pilihan dan kesepakatan rakyat dan negara sebagai perwujudan negara hukum..$^{23}$

Dengan demikian ada 3 (tiga) aspek pokok yang harus diperhatikan dalam penataan ruang yaitu: a) Aspek lingkungan hidup fisik umumnya dan sumber daya alam khususnya yang dimanfaatkan; b) Aspek masyarakat termasuk aspirasi sebagai pemanfaat; dan c) Aspek pengelola lingkungan fisik oleh pemerintah yang dibantu masyarakat, dengan memperhatikan dan mempertimbangkan kondisi dan potensi lingkungan fisik serta kebutuhan masyarakat agar pemanfaatan ruang tersebut dapat dilaksanakan secara berkelanjutan. ${ }^{24}$

Terkait dengan pelanggaran penataan ruang yang terjadi, hal ini disebabkan, antara lain: a) Potensi konflik antar wilayah. Konflik ini dapat berpotensi terjadi antara dua wilayah Kota atau Kabupaten atau lebih yang terletak pada satu kesatuan hamparan ekosistem; b) Potensi konflik antar sektor. Perbedaan kepentingan terhadap suatu obyek oleh dua sektor menjadi pemicu utama konflik ini. Misalnya pemanfaatan kawasan tertentu yang diperebutkan oleh sektor pertanian (pertanian), sektor kehutanan (kawasan lindung) dan sektor pariwisata (obyek wisata); dan c) Potensi konflik antar masyarakat dan pemerintah. Konflik ini terjadi karena perbedaan kepentingan antara masyarakat dengan pemerintah dalam menetapkan zona peruntukan ruang. ${ }^{25}$

Berikut ini adalah tabel perkara yang terkait penataan ruang yang penulis dapatkan dari laman Kementerian LHK tahun 2015 (statistik perkara tahun 2016-2017 belum ada), mulai dari proses perkara, tipologi perkara, dan status penyelesaian perkara: ${ }^{26}$

Tabel 3. Verifikasi Perkara Pidana Lingkungan Hidup dan Kehutanan Tahun 2015

\begin{tabular}{|c|l|r|}
\hline No & \multicolumn{1}{|c|}{ Proses Perkara Pidana LHK } & Jumlah Perkara Pidana \\
\hline 1 & Sampai P.21 & 118 Kasus \\
\hline 2 & Penyidikan & 23 Kasus \\
\hline 3 & $\begin{array}{l}\text { Pembuktian dan Pengumpulan data } \\
\text { dan Keterangan }\end{array}$ & 64 Kasus \\
\hline & \multicolumn{1}{|c|}{ Jumlah } & 205 Kasus \\
\hline
\end{tabular}

sumber: http://www.menlhk.go.id.

Juniarso Ridwan dan Achmad Sodik, op.cit. hlm. 159.---lihat Laporan Akhir BPHN, hlm. 124.

24 Fungsi-Tata-Ruang-Dalam-Menjaga-Kelestarian-Lingkungan-Hidup-Kota-Gorontalo, repository.ung.ac.id... Fungsi-Tata-Ruang-Dalam-Menjaga-Kelestarian-Lingkungan-,op. cit. hlm. 10.

25 ibid, hlm. 62-67.

26 http://www.menlhk.go.id/downlot.php?file=Statistik_KLHK_tahun_2015.pdf, (diakses 8 Agustus 2017, pukul 14.31 WIB). 
Tabel 4. Tipologi Perkara Pidana Lingkungan Hidup dan Kehutanan Tahun 2015

\begin{tabular}{|r|l|r|r|r|}
\hline \multirow{2}{*}{ No } & \multirow{2}{*}{ Tipologi kasus } & \multicolumn{2}{|c|}{ Proses Perkara } & \multirow{2}{*}{ Jumlah } \\
\cline { 3 - 4 } & & Penyidikan & \multicolumn{1}{c|}{ P21 } & \\
\hline 1 & Pembalakan liar & 0 Kasus & 43 Kasus & 43 Kasus \\
\hline 2 & Perambahan hutan & 8 Kasus & 28 Kasus & 36 Kasus \\
\hline 3 & $\begin{array}{l}\text { Peredaran Tumbuhan } \\
\text { dan Satwa Liar Illegal }\end{array}$ & 6 Kasus & 43 Kasus & 49 Kasus \\
\hline 4 & $\begin{array}{l}\text { Pencemaran lingkun- } \\
\text { gan }\end{array}$ & 4 Kasus & 4 Kasus & 8 Kasus \\
\hline 5 & Kebakaran hutan & 5 Kasus & 0 Kasus & 5 Kasus \\
\hline & Jumlah & 23 Kasus & 118 Kasus & 141 Kasus \\
\hline
\end{tabular}

sumber: http://www.menlhk.go.id.

Grafik 1.Status Penyelesaian Sengketa Lingkungan melalui pengadilan tahun 2015

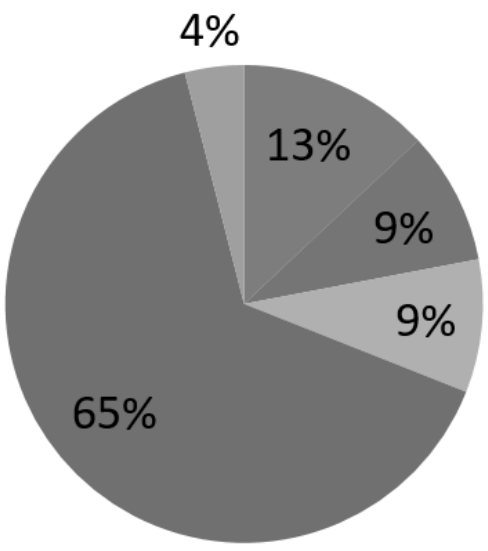

Proses Persidangan

Proses kasasi

Sengketa Limpahan

Telah diverifikasi

Inkracht

sumber: http://www.menlhk.go.id.

Jika melihat pada tabel-tabel di atas, maka kasus pelanggaran dan penyimpangan penataan ruang adalah didominasi pembalakan liar, hal inilah yang menyebabkan semakin berkurangnya kuantitas hutan di Indonesia sehingga jika terjadi pembiaran akan mengancam pembangunan berkelanjutan khususnya terkait penataan ruang dan lingkungan hidup.

Di sisi lain lemahnya penegakan hukum terhadap pelanggaran tata ruang serta ringannya sanksi yang dijatuhkan adalah persoalan utama terjadinya pelanggaran tersebut, padahal UU Penataan Ruang telah mengatur penerapan sanksi yaitu sanksi administrasi (Pasal 62-64), sanksi perdata (Pasal 66, 67 dan 75) dan sanksi pidana (Pasal 69-74). Sanksi pidana yang diatur dalam Pasal 69 sampai dengan 71 ditujukan pada perilaku yang melanggar kewajiban yang diatur dalam Pasal 61 yaitu: (a) Menaati rencana tata ruang yang telah ditetapkan; (b) Memanfaatkan ruang sesuai dengan izin pemanfaatan ruang dari pejabat yang berwenang; (c) Mematuhi ketentuan yang ditetapkan dalam izin pemanfaatan ruang dan (d) Memberikan akses terhadap kawasan yang oleh ketentuan peraturan perundang-undangan dinyatakan milik umum. Namun demikian, Pasal 62 dan 63 memberikan sanksi administratif terhadap 
perilaku serupa, sehingga dalam penerapannya akan menimbulkan kerancuan terkait sanksi yang akan diberikan. Disamping itu, ancaman hukuman yang dijatuhkan masih tergolong ringan sebagaimana diatur dalam Pasal 63 yakni peringatan tertulis; penghentian sementara kegiatan; penghentian sementara pelayanan umum; penutupan lokasi; pencabutan izin; pembatalan izin; pembongkaran bangunan; pemulihan fungsi ruang; dan/atau denda administratif. ${ }^{27}$

Oleh karena itu, penegakan hukum lingkungan tidak hanya ditujukan untuk memberikan hukuman kepada perusak atau pencemarlingkungan hidup.Tetapijuga ditujukan untuk mencegah terjadinya perbuatan atau tindakan yang dapat menimbulkan perusakan dan atau pencemaran lingkungan hidup. Oleh karena itu penegakan hukum lingkungan tidak hanya bersifat represif, tetapi juga bersifat preventif, $^{28}$ Sehingga hukum lingkungan bekerja di dalam menyelamatkan, melindungi, melestarikan lingkungan hidup dan melindungi keberlangsungan kehidupan umat manusia dari kemungkinan kerusakan lingkungan hidup. ${ }^{29}$

Penegakan hukum secara preventif terhadap pemanfaatan tata ruang yang mendukung kelestarian lingkungan hidup dapat dilakukan dengan mencegah berbagai kegiatan berupa pengambilan kebijakan yang dapat diindikasikan merusak tatanan lingkungan hidup serta memberikan kesadaran kepada masyarakat dan juga pengguna tata ruang tentang arti pentingnya pemanfaatan tata ruang sesuai dengan kebutuhan.

Demikian pula penegakan hukum secara represif harus diambil dengan tegas kepada siapapun yang melakukan pelanggaran dalam memanfaatkan tata ruang dan lingkungan hidup, baik terhadap pengambil kebijakan maupun masyarakat dan pengusaha yang kedapatan merusak lingkungan hidup berupa sanksi pidana (penjara dan denda), sanksi perdata (ganti kerugian dan atau tindakan tertentu) dan sanksi administrasi (paksaan pemerintah, uang paksa, dan pencabutan izin).

Mas Achmad Santosa ${ }^{30}$ menyatakan penegakan hukum administrasi di bidang lingkungan hidup memiliki beberapa manfaat strategis dibandingkan dengan perangkat penegakan hukum lainnya (perdata dan pidana), yaitu: a) dapat dioptimalkan sebagai perangkat pencegahan (preventif). Penegakan hukum administrasi (preventif) dapat lebih efisien dari sudut pembiayaan dibandingkan penegakan hukum pidana dan perdata; b) pembiayaan untuk penegakan hukum administrasi (rutinitas biaya pengawasan lapangan dan pengujian laboratorium) lebih murah dibandingkan dengan upaya pengumpulan bukti, investigasi lapangan, memperkerjakan saksi ahli untuk membuktikan aspek kausalitas (sebab akibat) dalam kasus pidana dan perdata, dan c) memberikan peluang yang lebih terhadap partisipasi masyarakat yang dilakukan mulai dari proses perijinan, pemantauan penataan, pengawasan, dan pengajuan keberatan serta 
meminta pejabat tata usaha negara untuk memberlakukan sanksi administrasi.

$\mathrm{Hal}$ ini sejalan dengan pandangan Ten Berge yang menyebutkan bahwa instrumen penegak hukum administrasi meliputi pengawasan dan penegakan sanksi. Pengawasan merupakan langkah preventif untuk memaksakan kepatuhan yang dapat dilakukan oleh pemerintah (pusat dan daerah) serta masyarakat ${ }^{31}$, sedangkan penerapan sanksi merupakan langkah represif untuk melaksanakan kepatuhan. ${ }^{32}$ Sanksi merupakan inti dari penegakan hukum administrasi ${ }^{33}$, yang secara umum dikenal beberapa macam sanksi dalam hukum administrasi, yaitu: paksaan pemerintah (bestuursdwang); penarikan kembali keputusan yang menguntungkan (izin, subsidi, pembayaran, dan sebagainya); pengenaan uang paksa oleh pemerintah (dwangsom); dan pengenaan denda administratif (administratieve boete). ${ }^{34}$

Di dalam UU Penataan Ruang, pengenaan sanksi tidak hanya diberikan kepada pemanfaatan ruang yang tidak sesuai dengan ketentuan perizinan pemanfaatan ruang semata (Pasal 37 ayat (2)), tetapi dikenakan pula kepada pejabat pemerintah yang berwenang yang menerbitkan izin pemanfaatan ruang yang tidak sesuai dengan rencana tata ruang. ${ }^{35}$ Jadi pengenaan sanksi merupakan salah satu upaya pengendalian pemanfaatan ruang, yang dimaksudkan sebagai perangkat tindakan pembinaan atas pemanfaatan ruang yang tidak sesuai dengan rencana tata ruang.Pemanfaatan ruang yang tidak sesuai dengan rencana tata ruang, baik yang dilengkapi dengan izin maupun yang tidak memiliki izin dikenai sanksi adminstratif, sanksi pidana penjara, dan/atau sanksi pidana denda. ${ }^{36}$

Terkait dengan hal tersebut di atas maka pemerintah menerbitkan UU No. 23 tahun 1997 yang sekarang sudah diganti lagi dengan UU No. 32 tahun 2009 tentang Perlindungan dan Pengelolaan Lingkungan Hidup, yang mengatur dan melaksanakan proteksi atau perlindungan terhadap sumber daya alam yaitu udara, tanah, air, pesisir dan laut, keanekaragaman hayati, pedesaan pedesaan, perkotaan, lingkungan sosial agar tidak mengalami kerusakan dan atau pencemaran. Dalam Pasal 1 UU tersebut di uraikan bahwa pengelolaan lingkungan adalah upaya terpadu untuk melestarikan fungsi lingkungan hidup yang meliputi kebijaksanaan penataan, pemanfaatan, pengembangan, pemeliharaan, pemulihan, pengawasan dan pengendalian lingkungan hidup. ${ }^{37}$

Namun penegakan hukum terkait penataan ruang ini masih belum konsisten dilakukan hal ini karena tanpa adanya peraturan zonasi ini , tidak ada dasar hukum yang kuat untuk menindak semua jenis pelanggaran, karena perizinan yang diterbitkan itu sendiri sesungguhnya "cacat hukum", sehingga apabila terjadi konflik

31 Peraturan Presiden No. 15 Tahun 2010 tentang Penyelenggaraan Penataan Ruang, Pasal 199 ayat (1) dan ayat (2).

32 Ridwan H.R., Hukum Administrasi Negara, (Jakarta: RajaGrafindo Persada) 2006, hlm. 311.

33 ibid, hlm.313.

34 ibid, hlm. 319.

35 http://erepo.unud.ac.id1163230ca82e87cb23dbfe065a21b41e2cdeb5.pdf, (diakses 7 April 2017, pukul 09.58 WIB).

36 http://digilib.unila.ac.id812915BAB\%20II.pdf, (diakses 07 April 2017, pukul 10.00 WIB).

37 Lihat penjelasan Undang-Undang Nomor 32 tahun 2009 tentang Perlindungan dan Pengelolaan Lingkungan Hidup. 
yang diselesaikan lewat lembaga peradilan pemerintah seringkali dikalahkan. Bagi aparat juga sulit untuk mengambil tindakan atas berbagai macam pelanggaran, karena tidak jelas pasal mana yang dilanggar dan tidak jelas juga sanksi yang akan diberikan. Kewajiban untuk menaati rencana tata ruang adalah kaidah perilaku yang sangat mendasar. Sebab, upaya apa pun yang dilakukan dalam penataan ruang tidak akan berguna jika tidak disertai dengan kepatuhan terhadap rencana tata ruang yang telahditetapkan. Ketika kepatuhan terhadap hukum mengendur karena pudarnya kesadaran hukum, ancaman sanksi mutlak diperlukan. Kebutuhan akan sanksi saat ini telah diakomodasi dalam UU Penataan Ruang (PR) Nomor 26 Tahun 2007. Saat ini, berdasarkan ketentuan Pasal 68 UUPR, penyidikan pelanggaran terhadap rencana tata ruang dapat diserahkan sepenuhnya kepada penyidik kepolisian dan penyidik pegawai negeri sipil yang diberi wewenang khusus sebagai penyidik yang membantu pihak kepolisian. ${ }^{38}$

Padahal tujuan pengenaan sanksi terhadap pelanggaran rencana tata ruang pada intinya adalah untuk mencegah timbulnya dampak negatif terhadap keselamatan lingkungan dan hidup warga. Sulitnya pembuktian setiap bentuk pelanggaran tata ruang dalam intensitas rendah, baik yang dilakukan oleh satu orang maupun korporasi, adalah sulitnya untuk langsung dibuktikan apakah perbuatan itu telah merusak lingkungan dan kehidupan warga atau tidak. Hal ini akan menjadi preseden bagi timbulnya banyak pelanggaran sejenis sehingga secara agregat berdampak negatif terhadap keselamatan lingkungan hidup dan masyarakat dalam jangka panjang. ${ }^{39}$

Pada akhirnya penegakan hukum terhadap pemanfaatan tata ruang demi kelestarian lingkungan hidup tidak hanya ditujukan untuk memberikan hukuman kepada perusak atau pencemar lingkungan hidup, tetapi juga ditujukan untuk mencegah terjadinya perbuatan atau tindakan yang dapat menimbulkan perusakan atau pencemaran lingkungan hidup.

\section{Solusi penegakan hukum penataan ruang dalam rangka mewujudkan pembangunan berkelanjutan}

Beranjak dari banyaknya pelanggaran tata ruang yang kalau dibiarkan justru semakin tidak terkendali dan dapat merusak lingkungan serta kehidupan, sebagaimana digambarkan dalam data statistik bencana Indonesia tahun 2017 per Maret 2017 (Tabel 1 dan tabel 2), bencana yang tercatat adalah: ${ }^{40}$

\footnotetext{
http://v2.bkprn.org/?p=644, (diakses 8 Agsustus 2017, pukul 14.54 WIB).

ibid.

40 http://dibi.bnpb.go.id/, (diakses 12 April 2017, pukul 09.12 WIB).
} 


\section{RUECHTSVINDING}

Media Pembinaan Hukum Nasional

Volume 6, Nomor 2, Agustus 2017

Tabel 1.Jumlah Kejadian Bencana, Korban, dan Dampaknya sampai bulan Maret 2017

\begin{tabular}{|c|c|c|c|c|c|c|c|c|c|c|c|}
\hline \multirow{3}{*}{ Jenis Bencana } & \multirow{3}{*}{$\begin{array}{l}\text { Jumlah } \\
\text { Kejadian }\end{array}$} & \multicolumn{3}{|c|}{ Korban (jiwa) } & \multicolumn{7}{|c|}{ Kerusakan (unit) } \\
\hline & & \multirow{2}{*}{$\begin{array}{c}\text { Meninggal } \\
\text { \& Hilang }\end{array}$} & \multirow[b]{2}{*}{$\begin{array}{l}\text { Luka- } \\
\text { Luka }\end{array}$} & \multirow{2}{*}{$\begin{array}{c}\text { Menderita \& } \\
\text { Mengungsi }\end{array}$} & \multicolumn{4}{|c|}{ Rumah } & \multirow{2}{*}{$\begin{array}{l}\text { Fasilitas } \\
\text { Kesehatan }\end{array}$} & \multirow{2}{*}{\begin{tabular}{c|} 
Fasilitas \\
Peribadatan
\end{tabular}} & \multirow{2}{*}{$\begin{array}{c}\text { Fasilitas } \\
\text { Pendidikar }\end{array}$} \\
\hline & & & & & $\begin{array}{l}\text { Rusak } \\
\text { Berat }\end{array}$ & \begin{tabular}{|c|} 
Rusak \\
Sedang
\end{tabular} & \begin{tabular}{|l} 
Rusak \\
Ringan \\
\end{tabular} & Terendam & & & \\
\hline BANJIR & 313 & 50 & 60 & 846.208 & 546 & \begin{tabular}{|l|}
61 \\
\end{tabular} & 634 & 133.537 & 16 & 101 & 169 \\
\hline $\begin{array}{l}\text { BANJIR DAN TANAH } \\
\text { LONGSOR }\end{array}$ & 22 & 16 & 6 & 87.962 & 98 & 192 & 1.765 & 13.626 & 0 & 1 & 8 \\
\hline $\begin{array}{l}\text { GELOMBANG PASANG } \\
\text { / ABRASI }\end{array}$ & 4 & 0 & 0 & 10.155 & 22 & 0 & 2 & 0 & 0 & 0 & 0 \\
\hline GEMPA BUMI & 4 & 0 & 19 & 0 & 7 & 0 & 75 & 0 & 0 & 3 & 7 \\
\hline $\begin{array}{l}\text { KEBAKARAN HUTAN } \\
\text { DAN LAHAN }\end{array}$ & 1 & 0 & 0 & 0 & 0 & 0 & 0 & 0 & 0 & 0 & 0 \\
\hline $\begin{array}{l}\text { KECELAKAAN } \\
\text { TRANSPORTASI } \\
\end{array}$ & 2 & 17 & 46 & 0 & 0 & 0 & 0 & 0 & 0 & 0 & 0 \\
\hline PUTING BELIUNG & 287 & 17 & 95 & 8.466 & 959 & 1.546 & 4.661 & 0 & 8 & 31 & 43 \\
\hline TANAH LONGSOR & 251 & 20 & 48 & 8.649 & 257 & 234 & 500 & 0 & 2 & 11 & 6 \\
\hline TOTAL & 884 & 120 & 274 & 961.440 & 1.889 & 2.033 & 7.637 & 147.163 & 26 & 147 & 233 \\
\hline
\end{tabular}

sumber: Data dibi.bnpb.go.id

Tabel 2. Data Bencana di Wilayah Indonesia

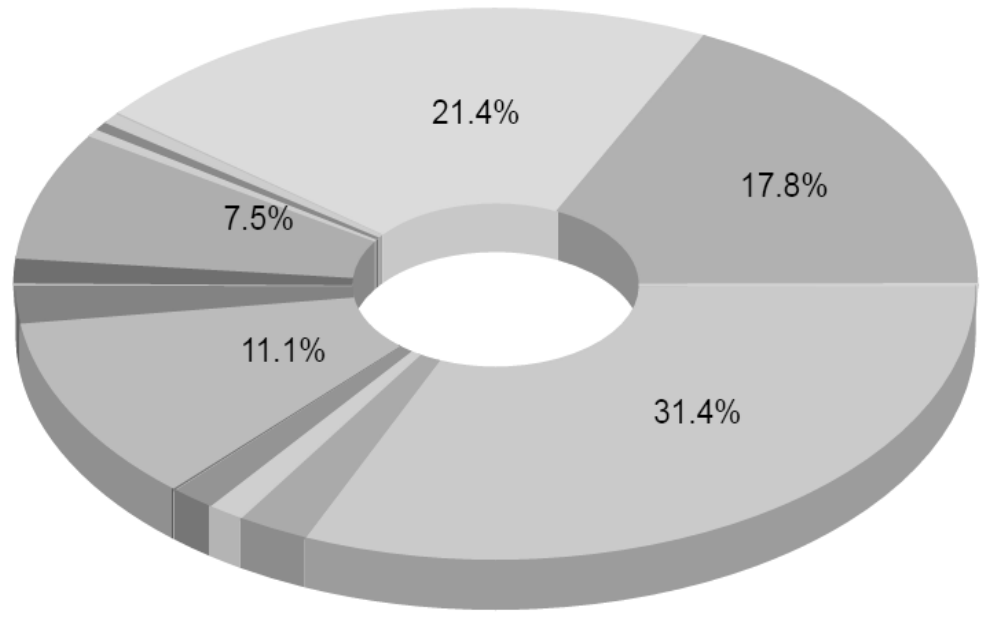

AKSI TEROR / SABOTASE

BANJIR

BANJIR DAN TANAH LONGSOR

GELOMBANG PASANG / ABRASI

GEMPA BUMI

GEMPA BUMI DAN TSUNAMI

HAMA TANAMAN

KEBAKARAN

KEBAKARAN HUTAN DAN LAHAN

KECELAKAAN INDUSTRI

KECELAKAAN TRANSPORTASI

KEKERINGAN

KELAPARAN

KLB

KONFLIK / KERUSUHAN SOSIAL

LETUSAN GUNUNG API

PERUBAHAN IKLIM

PUTING BELIUNG

TANAH LONGSOR

TSUNAMI

sumber: dibi.bnpb.go.id

Jika memperhatikan 2 (dua) tabel di atas, tentu menjadi sebuah keprihatinan bagi kita karena ada yang salah dalam hal implementasi penataan ruang di wilayah serta adanya indikasi pelanggaran penataan ruang baik yang dilakukan oleh individu, masyarakat, korporasi, dan pemerintah, padahal undang-undang ini telah mengamanatkan bahwa seluruh Provinsi, Kabupaten, Kota harus mempunyai Rencana Tata Ruang Wilayah (RTRW) yang digunakan sebagai acuan dalam melaksanakan pembangunan.

Oleh karena itu, maka penerapan sanksi administrasi harus dilakukan semaksimal mungkin, bahkan apabila dimungkinkan dapat 
dilakukan gugatan untuk membayar ganti rugi ${ }^{41}$ dan penuntutan secara pidana ${ }^{42}$ dalam hal terjadinya pelanggaran tata ruang yang bersifat masif dan terstruktur yang menyebabkan kehancuran lingkungan yang sangat luar biasa dan menimbulkan bencana dengan korban jiwa.

Menurut Sadjijono, demi keberlangsungan pembangunan yang berkelanjutan dan terjaganya kelestarian alam maka upaya yang dapat dilakukan antara lain meliputi: ${ }^{43}$

1. Partisipasi (participation). Setiap warga negara mempunyai hak dan kewajiban untuk mengambil bagian dalam proses bernegara, berpemerintahan serta bermasyarakat, baik secara langsung maupun melalui intermediasi institusi legitimasi yang mewakili kepentingannya mulai dari tahapan penyusunan kebijakan, pelaksanaan, evaluasi serta pemanfaatan hasil-hasilnya;

2. Penegakan Hukum (Rule of Law). Salah satu syarat kehidupan demokrasi adalah adanya penegakan hukum yang adil dan dilaksanakan tanpa pandang bulu untuk mewujudkan good governance dengan membangun sistem hukum yang sehat, baik perangkat lunak (soft ware), perangkat kerasnya (hard ware), maupun sumber daya manusia yang menjalankan sistemnya (human ware);

3. Transparansi (Transparancy). Keterbukaan adalah merupakan salah satu karakteristik good governance yang mencakup semua aspek aktivitas dan kepentingan public;

4. Daya tanggap (Responsiveness). Pembangunan good governance perlu memiliki daya tanggap terhadap keinginan maupun keluhan dari setiap stakeholders;

5. Orientasi bersama (Consencus Orientation). Good governance menjadi perantara kepentingan yang berbeda untuk memperoleh pilihan terbaik bagi kepentingan yang lebih luas;

6. Keadilan (Equity). Semua warga negara mempunyai kesempatan yang sama untuk memperoleh kesejahteraan;

7. Efektif dan efisien (Effectiveness and Efficiancy). Proses dan lembaga menghasilkan sesuai dengan apa yang telah digariskan dengan menggunakan sumber yang tersedia sebaik mungkin;

8. Akuntabilitas (Accountability). Para pembuat keputusan dalam pemerintahan, sektor swasta dan masyarakat (civil society) bertanggung jawab kepada publik dan lembaga stakeholders; dan

9. Visi Strategis (Strategic Vision). Para pemimpin dan publik harus mempunyai prespektif good governance dan pengembangan manusia yang luas serta jauh ke depan.

Berdasarkan pembahasan di atas, maka upaya-upaya yang dapat dilakukan untuk meminimalisir pelanggaran penataan ruang dan kritisnya penataan ruang serta lingkungan hidup, antara lain: a) melakukan inventarisasi dan evaluasi sumber daya alam dan lingkungan hidup. Inventarisasi dilakukan untuk meningkatkan pengenalan terhadap kuantitas dan kualitas sumber daya alam serta mengembangkan evaluasi terhadap daya 
dukung dan terjaminnya ketersediaan sumber alam yang berkelanjutan; b) konservasi hutan, tanah dan air. Hal ini dilakukan guna pelestarian fungsi dan daya dukung sumber alam hayati dan non hayati serta lingkungan hidup melalui penyelamatan hutan, tanah dan air sebagai sumber kekayaan alam dan lingkungan hidup; c) pembinaan terhadap peningkatan kualitas empat komponen terkait yaitu: sumberdaya manusia, kemampuan organisasi pemerintah, pelaku usaha, dan masyarakat dalam pengelolaan lingkungan hidup; d) pengendalian pencemaran lingkungan hidup yang diarahkan untuk mengurangi rendahnya kualitas dan terganggunya fungsi lingkungan hidup baik di darat laut, dan udara yang disebabkan oleh makin meningkatnya eksploitasi kegiatan pembangunan; e) rehabilitasi lahan kritis. Upaya ini dilakukan untuk memulihkan kemampuan hutan dan tanah yang rusak agar dapat produktif kembali yang dilakukan secara kontinyu, dan g) konsistensi dalam penegakan hukum. Lemahnya penegakan hukum terhadap pelanggaran penataan ruang berimplikasi terhadap meningkatnya pelanggaran terhadap lingkungan hidup. Dengan penegakan hukum yang konsisten dan tidak tebang pilih diharapkan terjadinya peningkatan ketertiban dan kepastian hukum dalam penataan ruang sehingga mendorong partisipasi masyarakat secara bertanggung jawab dan terjaminnya perlindungan hukum akan hak-hak masyarakat.

\section{Penutup}

\section{Kesimpulan}

Berdasarkan penelitian dapat disimpulkan bahwa implementasi penegakan hukum berdasarkan UU Penataan Ruang belum optimal dalam meminimalisir pelanggaran penataan ruang dikarenakan adanya potensi konflik antar wilayah, antar sektor, dan antar masyarakat dengan pemerintah. Di sisi lain lemahnya penegakan hukum lingkungan serta kecenderungan sanksi yang ringan tidak menimbulkan efek penjeraan terhadap pelaku pelanggaran penaataan ruang, sehingga menyebabkan permasalahan terkait penataan ruang dan penegakan hukumnya tidak berjalan efektif. Seharusnya hukum lingkungan bekerja di dalam menyelamatkan, melindungi, melestarikan lingkungan hidup dan melindungi keberlangsungan kehidupan umat manusia dari kemungkinan kerusakan lingkungan hidup. Oleh karena itu perlunya pengaturan penataan ruang demi terwujudnya ketertiban dalam penyelenggaraan penataan ruang, adanya kepastian hukum dan keadilan bagi seluruh pemangku kepentingan yang harus dilakukan secara cermat, proporsional, dan komprehensip sehingga terwujud pembangunan yang berkelanjutan (sustainable development).

Atas beberapa temuan diatas direkomendasikan untuk Pemerintah dan instansi terkait (POLRI, Kejaksaan, Pengadilan) harus memiliki komitmen dan political will yang kuat dalam penegakan hukum pelanggaran penataan ruang yang dilakukan secara cermat, proporsional, dan komprehensip dengan sanksi berjenjang dimulai peringatan, denda, pencabutan izin, dan sanksi pidana yang lebih berat dan tegas sebagai ultimum remedium, apalagi jika terjadi pelanggaran dan penyimpangan secara meluas terhadap penataan ruang yang mengakibatkan kerugian besar dan menimbulkan korban jiwa. Selanjutnya Pemerintah (pusat dan daerah) memetakan secara proporsional dan kontinyu peruntukan lahan sesuai kebutuhan dan keberlangsungan sumber daya dalam penataan ruang sesuai dengan karaketristik wilayahnya masing- 
masing. Kemudian melakukan penguatan forum bersama yang sudah ada dengan melibatkan $\mathrm{K} / \mathrm{L}$ terkait, LSM, masyarakat, dan akademisi dalam mengatasi permasalahan pelanggaran penataan ruang, dan melakukan sinkronisasi dan harmonisasi peraturan pusat dan daerah (provinsi, kab/kota) terkait pelaksanaan tata ruang untuk kepentingan nasional.

\section{Daftar Pustaka}

\section{Buku}

Amirudin \& Zainal Asikin, Pengantar Metode Penelitian Hukum, (Jakarta: Radja Grafindo Persada, 2004).

G. Kartasasmita, Administrasi Pembangunan (Perkembangan Pemikiran dan Prakteknya di Indonesia), (Jakarta: LP3ES, 1997).

Hasni, Hukum Penataan Ruang dan Penatagunaan Tanah, (Jakarta: PT RajaGrafindo Persada, 2010).

Kusumaatmadja, Mochtar, Konsep-konsep Hukum dalam Pembangunan, (Bandung: Alumni, 2002).

M Friedman, Lawrence, 1984, Hukum Amerika, Sebuah Pengantar, Terjemahan Wishnu Basuki, (Jakarta: Tatanusa Indonesia, 2001).

Machmud, Syahrul, Penegakan Hukum Lingkungan Indonesia, (Yogyakarta: Graha Ilmu,2012).

Manan, Bagir, Penegakan Hukum Yang Berkeadilan, dalam Bagir Manan, Menemukan Hukum Suatu Pencarian, (Jakarta: Asosiasi Advokat Indonesia, 2009).

Prasetianingsih, Rahayu, Negara Hukum yang Berkeadilan, (Bandung: Pusat Studi Kebijakan Negara, Fakultas Hukum UNPAD, 2011).

R. Ridwan H. Hukum Administrasi Negara (Jakarta: RadjaGrafindo Persada. 2006).

Rahardjo, Satjipto, Masalah Penegakan Hukum Suatu Tinjauan Sosiologis, (Bandung: Sinar Baru, 2009).

Rangkuti, Sri Sundari, Hukum Lingkungan Dan Kebijaksanaan Lingkungan Nasional. (Surabaya: Airlangga University Press, 2000), Edisi Kedua.

Ridwan, Juniarso dan Achmad Sodik, Hukum Tata Ruang (dalam Konsep Otonomi Daerah) (Bandung: Nuansa, 2008).

Sadjijono, Fungsi Kepolisian Dalam Pelaksanaan Good Governance, (Sleman: Laksbang Yogyakarta, 2010).
Soemitro, Ronny Haitijo, Metodologi Penemuan Hukum, (Jakarta: Ghalian Indonesia, 1982).

Soerjono, Soekanto dan Sri Mamudji, Penelitian Hukum Normatif: Suatu Tinjauan Singkat, (Jakarta: Raja Grafindo Persada, 2006).

\section{Makalah/Artikel/Laporan/Hasil Penelitian}

Laporan Akhir Kajian Hukum Tentang Penegakan Hukum Penataan Ruang dalam Kerangka Otonomi Daerah, (Jakarta: BPHN, 2014)

Pasaribu, Ifransko, Tesis, Kebijakan Hukum Pidana (Penal Policy) Dalam Pemberantasan Tindak Pidana Korupsi (Tinjauan Analisis Terhadap Pembebanan Pembuktian Dan Sanksi Dalam UU No. 31 Tahun 1999 Jo. UU No. 20 Tahun 2001, (Medan: Sekolah Pasca Sarjana Universitas Sumatera Utara, 2007).

\section{Internet}

http://kiprah.pu.go.id/edition/detail/41/ Menuju-100-0-100, (diakses 12 April 2017, pukul 09.42 WIB).

Majalah KIPRAH, http://kiprah.pu.go.id/, Volume 72 tahun XV, Maret-April 2016, hlm. 9. (diakses 12 April 2017, 10.15 WIB).

http://erepo.unud.ac.id1163230ca82e87cb23dbfe 065a21b41e2cdeb5.pdf, (diakses 7 April 2017, pukul 09.58 WIB).

http://dibi.bnpb.go.id/, (diakses 12 April 2017, 09.12 WIB).

http://www.bappenas.go.id/index.php/download_ file/view/9567/1781/., (diakses 26 Februari 2015. pukul 08.37 WIB).

Fungsi-Tata-Ruang-Dalam-Menjaga-KelestarianLingkungan-Hidup-Kota-Gorontalo, repository. ung.ac.id...Fungsi-Tata-Ruang-Dalam-MenjagaKelestarian-Lingkungan-, (diakses 7 April 2017, pukul10.10 WIB).

http://prepository.unhas.ac.idbitstreamhandle1 2345678920523BAB\%20II\%20TINJAUAN\%20 PUSTAKA\% 20 repository\% 20 unh as . pdfsequence=1, (dikases 07 April 2017, pukul $10.02 \mathrm{WIB})$.

http://www.bphn.go.iddatadocumentslaporan lengkap.pdf,(diakses 7 April 2017, pukul 09.24 WIB).

http://digilib.unila.ac.id812915BAB\%20II.pdf, (diakses 07 April 2017, pukul 10.00 WIB).

h t t p : / / k a b a r 24 . b is n i s. com / $\mathrm{read} / 20151105 / 16 / 489087 /$ pelanggaran- 
tata-ruang-data-194-perusahaan-di-kaltengdan-kalbar-diserahkan-ke-kpk\#\&gid=1\&pid=1, (diakses 8 Agustus 2017, pukul 13.27 WIB).

http://pktl.menlhk.go.id/index.php?pg=w2530y254 5c2610c2565v2620z2525\&id=k2460, (diakses 8 Agustus 2017, pukul 13.52 WIB).

http://v2.bkprn.org/?p=644, (diakses 8 Agsustus 2017, pukul 14.54 WIB).

\section{Peraturan}

Undang-Undang Dasar 1945, amandemen keempat. Undang-Undang No. 26 Tahun 2007 Tentang Penataan Ruang.
Undang-Undang Nomor 32 tahun 2009 tentang Perlindungan Dan Pengelolaan Lingkungan Hidup.

Undang-Undang No. 17 tahun 2007 tentang Rencana Pembangunan Jangka Panjang Nasional Tahun 2005-2025.

Peraturan Presiden No. 15 Tahun 2010 tentang Penyelenggaraan Penataan Ruang.

Rencana Pembangunan Jangka Panjang 2005-2025. 
"Halaman ini dikosongkan" 